\title{
Evaluasi Kinerja Berdasarkan Implementasi Sistem Pengendalian Internal
}

\author{
'Febrianty, ${ }^{2}$ Divianto \\ 'Politeknik PalComTech, 2Politeknik Negeri Sriwijaya \\ 'febrianty@palcomtech.ac.id 2'divi.kardin@gmail.com
}

\begin{abstract}
The purpose of this study is to evaluate the performance based on the implementation of Internal Control System (SPI) at the Sub-Branch Office of Bank XYZ Palembang. The sample in this study were 48 respondents of the Sub-Branch Office of Bank XYZ Palembang. Data analysis technique used is descriptive qualitative method through descriptions of recapitulation result of respondent's answer on research questionnaire. The results of this study indicate that performance management has started supported by the application of SPI is considered adequate. However, the limited implementation of performance appraisal for financial elements causes SPI performance for the completion of follow-up audit findings at the Branch Office is not considered optimal. Therefore, attention needs to be applied to the SPI which also focuses on non-financial elements that also greatly support the company's performance either directly or indirectly. This research is expected to provide a description of the correlation between company performance with effective and efficient SPI implementation especially related to the completion of follow up on audit findings.
\end{abstract}

Key Words: internal control system, performance, evaluation, bank

\begin{abstract}
Abstrak
Tujuan penelitian adalah untuk mengevaluasi kinerja berdasarkan implementasi Sistem Pengendalian Intern (SPI) pada Kantor Cabang Pembantu Bank XYZ Palembang. Sampel dalam penelitian ini sebanyak 48 responden pegawai Kantor Cabang Pembantu Bank XYZ Palembang. Teknik analisis data adalah deskriptif kualitatif melalui pendeskripsian hasil rekapitulasi jawaban responden pada kuesioner penelitian. Hasil penelitian ini menunjukan bahwa manajemen kinerja sudah mulai terdukung dengan penerapan SPI yang dinilai sudah memadai. Akan tetapi masih terbatasnya penerapan penilaian kinerja untuk unsur finansial menyebabkan kinerja SPI untuk penyelesaian tindak lanjut temuan audit pada Kantor Cabang dinilai belum optimal. Oleh karena itu, perlu perhatian penerapan SPI yang juga memfokuskan pada unsur non finansial yang juga sangat menunjang kinerja perusahaan baik langsung maupun tidak langsung. Penelitian ini diharapkan mampu memberikan suatu gambaran mengenai kaitanevaluasi kinerja perusahaan dengan implementasi SPI yang efektif dan efisien khususnya yang berkaitan dengan penyelesaian tindak lanjut terhadap temuan audit.
\end{abstract}

Kata kunci: sistem pengendalian internal, kinerja, evaluasi, Bank.

Diterima: 25 Mei 2017; Revisi: 5 Juli 2017; Disetujui: 10 Agustus 2017 


\section{PENDAHULUAN}

Keberhasilan Sistem Pengendalian Intern (SPI) salah satunya ditunjukkan dengan adanya kecenderungan berkurangnya jumlah temuan audit. Hal ini terkait juga dengan bagaimana SPI yang diterapkan di perusahaan. Menurut Niswonger Warren, Reeve, Fees (2000), tujuan dari pengendalian internal yaitu memberikan jaminan yang wajar bahwa setiap bank melakukan suatu kontrol yang dapat meminimalisasi penyimpanganpenyimpangan yang akan terjadi. Berkurangnya penyimpangan-penyimpangan atau bahkan tidak ada sama sekali, menunjukkan peningkatan pencapaian kinerja bank yang bersangkutan.

Hal yang terkait dengan SPI yakni salah satunya pada penyelesaian tindak lanjut temuan audit yang selama ini dianggap bukanlah merupakan hal yang sifatnya perlu didahulukan dalam penyelesaiannya oleh pihak manajemen Kantor Cabang Pembantu. Padahal ini merupakan salah satu komponen dalam penilaian kinerja bank, terkait dengan masih utamanya ukuran-ukuran finansial dalam pencapaian target bagi Kantor Cabang Pembantu dalam mengukur kinerja keberhasilan. Oleh karenanya pekerjaanpekerjaan yang bersifat non-finansial atau administrasi termasuk tindak lanjut temuan audit dirasa masih kurang mendapatkan supervisi untuk diselesaikan. Hal yang cukup beralasan apabila manajemen Kantor Cabang (khususnya Kepala Cabang Pembantu) lebih memperhatikan pencapaian target-target finansial dibandingkan dengan pekerjaan yang non-finansialnya. Oleh karena penilaian kinerja seorang Kepala Cabang Pembantu yang dinyatakan berhasil, sampai dengan akhir tahun penilaian lebih fokus dinilai berdasarkan keberhasilannya didalam mencapai target-target finansial yang diberikan kepadanya dibandingkan keberhasilannya dari segi non-finansial atau administrasi yang tercermin dari unsur penilaian kinerja seorang Kepala Cabang Pembantu yang lebih memfokuskan pada unsur finansial. Sehingga bagi seorang Kepala Cabang Pembantu yang telah berhasil mencapai target-target finansialnya, tidak terpenuhinya pekerjaan yang bersifat non-finansial atau administrasi tidak akan dirasakan mengganggu kinerjanya.

Adanya peraturan-peraturan bagi perbankan yang harus melaporkan kegiatan serta aktivitasnya pada Bank Sentral maupun pihak-pihak yang terkait dengan penilaian bagi bank membuat diperlukannya target pekerjaan yang bersifat non finansial atau administrasi semakin diperlukan terlebih lagi dengan akan diterapkannya sistem 
manajemen risiko bagi perbankan yang dikenal dengan Bassel II membuat perbankan harus dapat mengantisipasi perbaikan-perbaikan dalam pelaksanaan perbankan termasuk perkerjaan yang bersifat non-finansial sebagai bentuk supervisi dari manajemen.

Berdasarkan Peraturan Bank Indonesia Nomor I3/2/PBI/20 I I tanggal I2 Januari 201 I mengenai Pelaksanaan Fungsi Kepatuhan Bank Umum. Fungsi Kepatuhan meliputi serangkaian tindakan/langkah-langkah yang bersifat pencegahan dalam memastikan bahwa kebijakan, ketentuan, sistem, dan prosedur, serta kegiatan usaha yang dilakukan oleh pihak Bank telah sesuai dengan ketentuan BI dan peraturan perundangundangan yang berlaku, termasuk bagi Bank Umum Syariah dan Unit Usaha Syariah sesuai dengan Prinsip Syariah, serta memastikan kepatuhan Bank terhadap komitmen yang dibuat oleh pihak Bank kepada $\mathrm{BI}$ dan atau otoritas pengawas lain yang berwenang.

Oleh karena itu, dalam rangka memastikan fungsi kepatuhan berjalan dengan baik maka SPI yang dilaksanakan oleh perbankan merupakan bagian dari pelaksanaan manajemen risiko. Pedoman Standar Sistem Pengendalian Intern Bagi Bank Umum (20I3) bahwa pengendalian intern bank terdiri dari 5 elemen utama yang satu sama lain saling berkaitan, yaitu: pengawasan oleh manajemen dan kultur pengendalian, identifikasi dan penilaian risiko, kegiatan pengendalian dan pemisahan fungsi, sistem akuntansi, informasi dan komunikasi, serta kegiatan pemantauan dan tindakan koreksi penyimpangan/kelemahan. Dengan demikian, lambat atau cepatnya penyelesaian tindak lanjut temuan audit khususnya tidak terlepas dari kemampuan dan motivasi dari pihak manajemen kantor cabang pembantu untuk selalu memonitor dan melakukan supervisi dengan menggunakan sistem informasi yang cepat dan tepat sehingga tindak lanjut terhadap temuan audit tersebut dapat segera diselesaikan.

Dalam perspektif pembelajaran dan pertumbuhan Balance Scorecard yang dikemukakan oleh Kaplan dan Norton (2000), perspektif pembelajaran mengacu pada tiga prinsip yaitu, people, system, dan organization procedure. Tujuan utama memasukkan kinerja ini antara lain adalah mendorong perusahaan menjadi learning organization. Perspektif keuangan, pelanggan, dan sasaran dari proses bisnis internal, dapat mengungkapkan kesenjangan (gap) yang besar antara kemampuan yang ada dari orang (people), system dan procedure dengan apa yang dibutuhkan untuk mencapai kinerja yang 
handal. Dalam rangka memperkecil kesenjangan tersebut perusahaan harus melakukan investasi dalam bentuk peningkatan kemampuan sistem dan teknologi informasi, meluruskan prosedur dan perbaikan rutinitas serta reskilling employees, ada tiga faktor yang perlu diperhatikan yaitu: Kemampuan Pegawai, Kemampuan Sistem Informasi, dan Motivasi Pemberdayaan dan Keserasian Individu.

Berdasarkan hasil pemeriksaan yang telah dilakukan oleh bank sentral terhadap Bank XYZ ditemukan adanya temuan yang berulang dalam artian temuan sebelumnya belum ditindaklanjuti oleh auditee (dalam hal ini Kantor Cabang Pembantu) baik temuan dari pihak intern maupun temuan dari pihak ekstern. Selain itu masih tingginya jumlah temuan yang belum ditindaklanjuti oleh Kantor Cabang Pembantu juga merupakan salah satu pengurang dari performance manajemen dalam hal internal control yang merupakan salah satu fungsi dari manajemen sesuai dengan Peraturan Bank Indonesia Nomor 13/2/PBI/20II tanggal 12 Januari 20II tentang Pelaksanaan Fungsi Kepatuhan Bank Umum.

Berdasarkan sembilan proses bisnis yang menjadi sasaran audit pada Bank XYZ terdapat temuan audit yang sering terjadi dan ditemukan kembali permasalahan yang sama pada periode audit berikutnya dalam suatu proses bisnis. Proses bisnis tersebut terutama adalah akuntansi dan pelaporan, manajemen simpanan pihak ketiga dan manajemen kredit. Tiga proses bisnis tersebut mengisyaratkan bahwa pihak manajemen bank harus benar-benar dapat mengantisipasi kemungkinan risiko yang ditimbulkan. Hal ini disebabkan proses bisnis tersebut dapat menimbulkan baik risiko reputasi, likuiditas, maupun risiko kredit bagi Bank XYZ sehingga perlu diupayakan agar penyelesaian tindak lanjut temuan audit dapat diselesaikan tepat pada waktunya baik temuan audit internal maupun audit eksternal.

Dengan kurang diperhatikannya penyelesaian tindak lanjut temuan audit oleh manajemen Kantor Cabang Pembantu akan mengakibatkan laporan penyelesaian tindak lanjut temuan audit pada pihak-pihak yang terkait sebagai pengawas maupun sebagai regulator perbankan secara keseluruhan tidak sesuai yang telah disepakati sehingga akan dapat memberikan nilai yang kurang baik bagi manajemen bank secara keseluruhan yang akhirnya menimbulkan risiko reputasi atau penilaian buruk atas kinerja dari Bank XYZ. Oleh karena itu, dalam mengupayakan penyelesaian tindak lanjut temuan audit agar dapat segera ditindak lanjuti diperlukan langkah-langkah ataupun metode yang dapat 
memacu manajemen Kantor Cabang Pembantu untuk segera dapat menyelesaikan tindak lanjut temuan audit tersebut termasuklah evaluasi kinerja atas implementasi SPI. Apakah implementasi SPI yang dilakukan mendukung atau tidak mendukung peningkatan kinerja perusahaan. Tujuan evaluasi kinerja adalah untuk menjamin pencapaian sasaran atau tujuan perusahaan. Sedangkan maksud dari evaluasi kinerja adalah untuk mengetahui: Pencapaian sasaran perusahaan, Pencapaian sasaran unit kerja, Pencapaian sasaran kelompok, dan Pencapaian sasaran individu (Simanjuntak 2005).

Penelitian yang dilakukan oleh Tresnawati (2012) mengenai Pengaruh Efektifitas Pengendalian Intern Terhadap Kinerja Instansi Pemerintah di Dinas Pendapatan Daerah Kota Bandung. Hasil penelitian menunjukkan pengendalian internal memiliki pengaruh positif terhadap kinerja pada Dinas Pendapatan Daerah Kota Bandung. Selanjutnya penelitian Tiasari (2013) mengenai Hubungan Antara Pengendalian Internal dengan Akuntabilitas Kinerja Instansi Pemerintah Dinas Pendapatan Provinsi Jawa Timur. Hasil penelitiannya menyatakan bahwa pengendalian internal memiliki hubungan dengan akuntabilitas kinerja instansi pemerintahan. Jika Kontrol internal yang lebih efektif dilakukan, maka akan semakin baik pula kinerja lembaga-lembaga yang akan semakin meningkatkan Akuntabilitas pemerintah. Penelitian Zamzami dan Ihda Arifin Faiz (20I5) mengenai Evaluasi Implementasi Sistem Pengendalian Internal: Studi Kasus pada Sebuah Perguruan Tinggi Negeri. Hasil penelitian menyatakan secara umum SPI pada PTN X telah dijalankan dengan baik dan sesuai SPIP. Akan tetapi, perlu pembenahan dalam aspek layanan pengadaan barang dan jasa, dokumentasi penilaian resiko, dan pengembangan aplikasi.

Berdasarkan latar belakang masalah di atas, masalah yang diteliti dirumuskan dalam pertanyaan penelitian yakni: bagaimana evaluasi kinerja berdasarkan implementasi Sistem Pengendalian Intern (SPI) pada Kantor Cabang Pembantu Bank XYZ Palembang? Hasil penelitian ini diharapkan dapat memberikan kontribusi kepada pihak manajemen Kantor Cabang Bank XYZ Palembang mengenai efektivitas dan efisiensi dari pelaksanaan SPI untuk menunjang pencapaian atau peningkatan kinerja perusahaan. 


\section{METODE}

\section{Desain Penelitian}

Menurut pendekatannya penelitian ini menggunakan dua pendekatan yaitu:

I) Pendekatan evaluasi formatif, yaitu untuk membandingkan suatu kejadian dan kegiatan dengan standar yang telah ditetapkan sehingga diperoleh umpan balik peningkatan kualitas kegiatan.

2) Penelitian survey, yaitu penelitian berdasarkan pada data sampel dari populasi.

Menurut tingkat eksplanasi, penelitian ini menggunakan penelitian komparatif, yaitu penelitian yang bersifat membandingkan dengan mencari fakta yang ada di perusahaan dengan interprestasi yang tepat berdasarkan pada literatur kepustakaan.

\section{Sampel}

Sampel dalam penelitian adalah seluruh pegawai pada Kantor Cabang Pembantu Bank XYZ Palembang, yang berjumlah 50 orang. Akan tetapi dikarenakan 2 kuesioner cacat data maka yang akan diolah hanya 48 kuesioner dari 48 responden.

\section{Jenis dan Metode Pengumpulan Data}

Data yang dibutuhkan dalam penelitian ini adalah data sekunder. Data Sekunder, yaitu data yang telah tersedia yang berasal dari perusahaan yang berupa struktur organisasi, job description, data Perkembangan Bobot Penilaian Sasaran Kerja Kantor Cabang Pembantu Bank XYZ Palembang (periode 20II-20l4), standar operasional prosedur, dan lain sebagainya. Metode pengumpulan data yang dilakukan penulis dalam penelitian ini adalah sebagai berikut : wawancara, dokumentasi, dan penyebaran kuisioner.

\section{Teknik Analisis Data}

Teknik analisis data yang digunakan adalah metode deskriptif kualitatif melalui pendeskripsian hasil rekapitulasi jawaban responden pada kuesioner penelitian.

\section{Indikator Identifikasi Evaluasi Kinerja Berdasarkan Implementasi SPI}

Indikator identifikasi evaluasi kinerja berdasarkan implementasi SPI pada Kantor Cabang Pembantu Bank XYZ Palembang adalah sebagai berikut:

a. Untuk mengetahui kinerja Kantor Cabang Pembantu Bank XYZ Palembang apakah didukung dengan SPI yang sudah memadai.

b. Kinerja Kantor Cabang Pembantu Bank XYZ Palembang yang belum tercapai/menurun apakah dimasukkan sebagai kendala dalam pelaksanaan SPI. 
c. Penilaian kinerja Kantor Cabang Pembantu Bank XYZ Palembang apakah didukung dengan kecukupan proses penyelesaian tindak lanjut temuan audit intern.

d. Penilaian kinerja pegawai telah mencakup penyelesaian temuan audit dan/atau aspek non finansial.

\section{Indikator Identifikasi Kinerja Kantor Cabang Pembantu Bank XYZ Palembang}

Indikator identifikasi penilaian kinerja pada Kantor Cabang Pembantu Bank XYZ Palembang, adalah sebagai berikut :

a. Apakah penilaian kinerja Proses Bisnis Kantor Cabang Pembantu Bank XYZ Palembang dipengaruhi oleh temuan audit yang sering terjadi dan berulang hal yang sama.

b. Penilaian kinerja Proses Bisnis pada Kantor Cabang Pembantu Bank XYZ Palembang dipengaruhi oleh faktor yang menyebabkan proses bisnis sering menjadi temuan audit

c. Apakah Penilaian kinerja proses bisnis pada Kantor Cabang Pembantu Bank XYZ Palembang dipengaruhi oleh lamanya penyelesaian temuan audit.

\section{HASIL DAN PEMBAHASAN}

\section{Gambaran Umum Penilaian Kinerja pada Kantor Cabang Pembantu Bank XYZ Palembang}

Penilaian kinerja pegawai Bank XYZ Palembang dilakukan sekali dalam satu tahun pada bulan Januari untuk periode I Januari sampai dengan 3I Desember tahun sebelumnya. Khusus untuk penilaian kinerja Kantor Cabang formulir pengisian sasaran kerja ditentukan oleh Divisi Pembinaan Bisnis Cabang Kantor Pusat Bank XYZ berdasarkan hasil keputusan dewan Direksi dengan mempertimbangkan saran dan usulan dari divisi-divisi terkait yang terlibat secara operasional dengan kinerja dan administrasi kantor cabang serta dengan mempertimbangkan berbagai risiko baik finansial maupun non finansial.

Penilaian kinerja terhadap sasaran kerja Kantor Cabang Bank XYZ sampai dengan tahun 2015 masih merupakan sasaran yang berhubungan dengan data akuntansi maupun data non finansial. Begitu pula dengan penilaian kinerja unit kerja (Seksi, Kantor 
Cabang Pembantu serta Pembantu Pimpinan Cabang) sampai saat ini masih berkisar pada target yang berhubungan dengan data finansial.

Tabel I. Crosstabulation (Tabulasi Silang) antara Tingkat Usia dengan Jenis Kelamin Responden

\begin{tabular}{|c|c|c|c|c|}
\hline \multirow{2}{*}{ No } & \multirow{2}{*}{$\begin{array}{c}\text { Tingkat usia Responden } \\
\text { (tahun) }\end{array}$} & \multicolumn{2}{|c|}{ Jenis Kelamin } & \multirow{2}{*}{ Jumlah } \\
\hline & & Pria & Wanita & \\
\hline 1 & $<25$ & 8 & 3 & II \\
\hline 2 & $25-30$ & 9 & 7 & 16 \\
\hline 3 & $30-40$ & 4 & 5 & 9 \\
\hline 4 & $40-50$ & 4 & 3 & 7 \\
\hline 5 & $>50$ & 2 & 2 & 4 \\
\hline & Jumlah & 28 & 20 & 48 \\
\hline
\end{tabular}

Sumber: diolah dari data primer

\section{Gambaran Umum Responden}

Berdasarkan 50 kuesioner yang dikirim kepada seluruh pegawai Kantor Cabang Pembantu Bank XYZ Palembang, kuesioner yang kembali dan dijawab oleh pegawai Kantor Cabang Pembantu Bank XYZ Palembang sejumlah 48 kuesioner. Pegawai Kantor Cabang Pembantu Bank XYZ Palembang yang tidak mengirimkan kembali kuesioner adalah dua orang. Deskripsi responden akan memberikan gambaran karakteristik responden yang diukur dengan skala nominal yang disajikan penulis dalam bentuk tabulasi silang.

Tabel 2. Crosstabulation (Tabulasi Silang) Tingkat Pendidikan dengan Jenis Kelamin Responden

\begin{tabular}{|c|c|c|c|c|}
\hline \multirow{2}{*}{ No } & \multirow{2}{*}{ Latar belakang pendidikan } & \multicolumn{2}{|c|}{ Jenis Kelamin } & \multirow{2}{*}{ Jumlah } \\
\hline & & Pria & Wanita & \\
\hline 1 & Diploma & 7 & 8 & 15 \\
\hline 2 & $\begin{array}{l}\text { Sarjana Strata I atau sedang } \\
\text { menempuh strata } 2\end{array}$ & 16 & 10 & 26 \\
\hline 3 & Sarjana strata 2 & 5 & 2 & 7 \\
\hline & Jumlah & 28 & 20 & 48 \\
\hline
\end{tabular}

Sumber: diolah dari data primer

Berdasarkan Tabel I, tingkat usia responden dominan berada di kisaran umur 25 - 30 tahun sebanyak 16 orang. Responden dengan latar belakang pendidikan SI (sedang menempuh S2) dominan sebanyak 26 orang, ditunjukkan pada Tabel 2. Sedangkan tabel 3., menunjukkan lama masa kerja responden dominan 6 - 10 tahun sebanyak 20 orang $(44,44 \%)$. 
Tabel 3. Lama Masa Kerja Responden

\begin{tabular}{lcc}
\hline \multicolumn{1}{c}{ Usia (tahun) } & Frekuensi & Persen \\
\hline kurang dari 5 & 10 & 22,22 \\
$6-10$ & 20 & 44,44 \\
$10-15$ & 18 & 37,50 \\
Total & 48 & 100,00
\end{tabular}

Sumber: diolah dari data primer

\section{Komponen Penilaian Kinerja}

Penilaian kinerja pegawai Bank $X Y Z$ yang dinilai meliputi tiga komponen, pertama sasaran kerja (bagi pejabat kepala seksi ke atas) atau tugas utama (bagi pelaksana dan penyelia), kedua ketrampilan kunci (maksimal 5 dari II unsur ketrampilan kunci) dan ketiga kompetensi (maksimal 5 dari 16 dimensi kompetensi). Bobot dari masing-masing komponen berbeda-beda bobot penilaian terbesar adalah sasaran kerja/tugas utama. Selain itu persentase perbandingan untuk masing-masing jabatan juga berbeda-beda dengan tingkatan pejabat yang lebih tinggi bobot sasaran kerja/tugas utama semakin besar. Persentase komponen penilaian kinerja sebagaimana Tabel 4.

Tabel 4. Persentase Komponen Penilaian Kinerja

\begin{tabular}{lcccc}
\hline \multicolumn{1}{c}{ Keterangan } & $\begin{array}{c}\text { Sasaran Kerja/ } \\
\text { Tugas utama }\end{array}$ & $\begin{array}{c}\text { Kompetensi } \\
\text { (\%) }\end{array}$ & $\begin{array}{c}\text { Ketrampilan } \\
\text { Kunci }\end{array}$ & $\begin{array}{c}\text { Total } \\
\text { (\%) }\end{array}$ \\
\hline Cabang & 60 & 20 & 20 & 100 \\
Seksi dan Wa. Kacab & 60 & 20 & 20 & 100 \\
Pelaksana dan Penyelia & 65 & 25 & 25 & 100 \\
\hline
\end{tabular}

Sumber: Divisi Pengembangan Sumber Daya Manusia Bank XYZ

Sasaran kerja atau tugas utama merupakan sasaran atau tugas yang harus dilakukan dan dicapai oleh pegawai sesuai dengan level yang telah ditentukan dalam sistem manajemen kinerja. Sedangkan kompetensi merupakan kemampuan yang ada pada diri pegawai dalam melakukan pekerjaan. Adapun ketrampilan kunci merupakan keterampilan paling dasar yang harus dimiliki oleh pegawai untuk menduduki posisi pekerjaan yang dilakukan. Sasaran kerja atau tugas utama merupakan target atau tugas utama yang harus dicapai dan dilakukan serta dikerjakan oleh pegawai yang merupakan penjabaran dari target keseluruhan Bank XYZ yang di tetapkan berdasarkan hasil RUPS, sehingga merupakan target yang harus dicapai oleh seluruh jajaran pegawai Bank XYZ. Sasaran kerja atau tugas utama yang harus dicapai untuk masing-masing unit kerja tidak 
sama. Hal ini sesuai dengan sasaran atau tugas yang akan dicapai untuk masing-masing unit kerja sesuai dengan yang telah ditentukan.

Penilaian kinerja untuk Kepala Cabang sejak tahun 2005 sesuai dengan usulan dari Divisi yang mensupervisi (dalam hal ini Divisi Pengelolaan Bisnis Cabang) telah memasukan unsur adminitrasi dan internal control dalam penilaian kinerja Kepala Cabang. Hal ini dalam upaya memperbaiki kinerja administrasi dari Bank XYZ agar dapat lebih diperhatikan oleh seluruh jajaran pegawai dan dengan pertimbangan Kepala Cabang merupakan penanggung jawab terlaksananya kegiatan operasional Kantor Cabang. Meskipun sasaran kerja Kepala Cabang sudah memasukan unsur administrasi dan internal kontrol namun sasaran kerja ini belum menyentuh pada Kepala unit kerja yang membawahi langsung kegiatan operasional sehingga Kepala Cabang masih mempunyai beban kerja yang berat untuk terus memantau pelaksanaannya.

\section{Evaluasi Kinerja Berdasarkan Implementasi SPI}

Hasil rekapitulasi evaluasi kinerja berdasarkan implementasi SPI melalui kuesioner kepada 48 (empat puluh sembilan) pegawai Kantor Cabang Pembantu Bank $X Y Z$ Palembang sebagai responden untuk masing-masing item pernyataan adalah sebagai berikut:

a. Mengetahui kinerja Kantor Cabang Pembantu Bank XYZ Palembang apakah didukung dengan SPI yang sudah memadai;

\section{Tabel 5. Jawaban responden untuk Mengetahui Kinerja Kantor Cabang Pembantu Bank XYZ Palembang Apakah didukung dengan SPI yang Sudah Memadai}

\begin{tabular}{|c|c|c|c|c|c|}
\hline \multirow{3}{*}{ Pernyataan /Pertanyaan } & \multicolumn{4}{|c|}{ Jawaban } & \multirow{3}{*}{ total } \\
\hline & \multicolumn{2}{|c|}{ tidak } & \multicolumn{2}{|c|}{ ya } & \\
\hline & JLH & $\%$ & JLH & $\%$ & \\
\hline $\begin{array}{l}\text { Kinerja perusahaan didukung oleh SPI yang sudah dilakukan } \\
\text { perusahaan dengan proses yang benar }\end{array}$ & 2 & 4 & 46 & 96 & 48 \\
\hline $\begin{array}{l}\text { Kinerja perusahaan didukung oleh SPI yang dilaksanakan } \\
\text { perusahaan sesuai dengan kondisi, kriteria, dan sebab akibat }\end{array}$ & 4 & 8 & 44 & 92 & 48 \\
\hline $\begin{array}{l}\text { Kinerja perusahaan didukung dengan ketersediaan } \\
\text { rekomendasi atas penerapan SPI }\end{array}$ & 14 & 29 & 34 & 71 & 48 \\
\hline Kinerja perusahaan didukung dengan tersedianya & & & & & \\
\hline $\begin{array}{l}\text { komunikasi terlebih dahulu sehubungan dengan pelaksanaan } \\
\text { pengendalian intern }\end{array}$ & 0 & 0 & 48 & 100 & 48 \\
\hline $\begin{array}{l}\text { Kinerja perusahaan didukung dengan hasil pengawasan } \\
\text { dalam pengendalian intern dimasukkan ke dalam laporan } \\
\text { hasil pemeriksaan }\end{array}$ & I & 2 & 47 & 98 & 48 \\
\hline
\end{tabular}


Sumber: diolah dari kuesioner penelitian, 2016

Berdasarkan hasil perhitungan atas jawaban pernyataan/ pertanyaan di atas skor terendah untuk jawaban tidak yang diberikan oleh pegawai Kantor Cabang Pembantu Bank XYZ Palembang adalah sebesar 29\% (item ketiga) sedangkan skor tertinggi adalah $100 \%$ (item keempat) untuk jawaban ya. Skor tersebut masih termasuk ke dalam klasifikasi memadai. Hal ini berarti pelaksanaan sistem pengendalian intern sudah memadai. Akan tetapi tetap harus menjadi perhatian pihak Kantor Cabang Pembantu Bank XYZ Palembang, untuk selalu menyediakan rekomendasi atas penerapan SPI yang dilakukan pihak bank agar SPI dapat berjalan secara efektif dan efisien agar kinerja Bank XYZ lebih baik. Disamping itu, pihak yang dinilai (auditee) dan karyawan menjadi lebih baik dalam bekerja.

b. Kinerja Kantor Cabang Pembantu Bank XYZ Palembang yang belum tercapai/menurun apakah dimasukkan sebagai kendala dalam pelaksanaan SPI:

Tabel 6. Jawaban responden untuk mengetahui Kinerja Kantor Cabang Pembantu Bank XYZ Palembang yang belum tercapai/menurun apakah dimasukkan sebagai kendala dalam pelaksanaan SPI

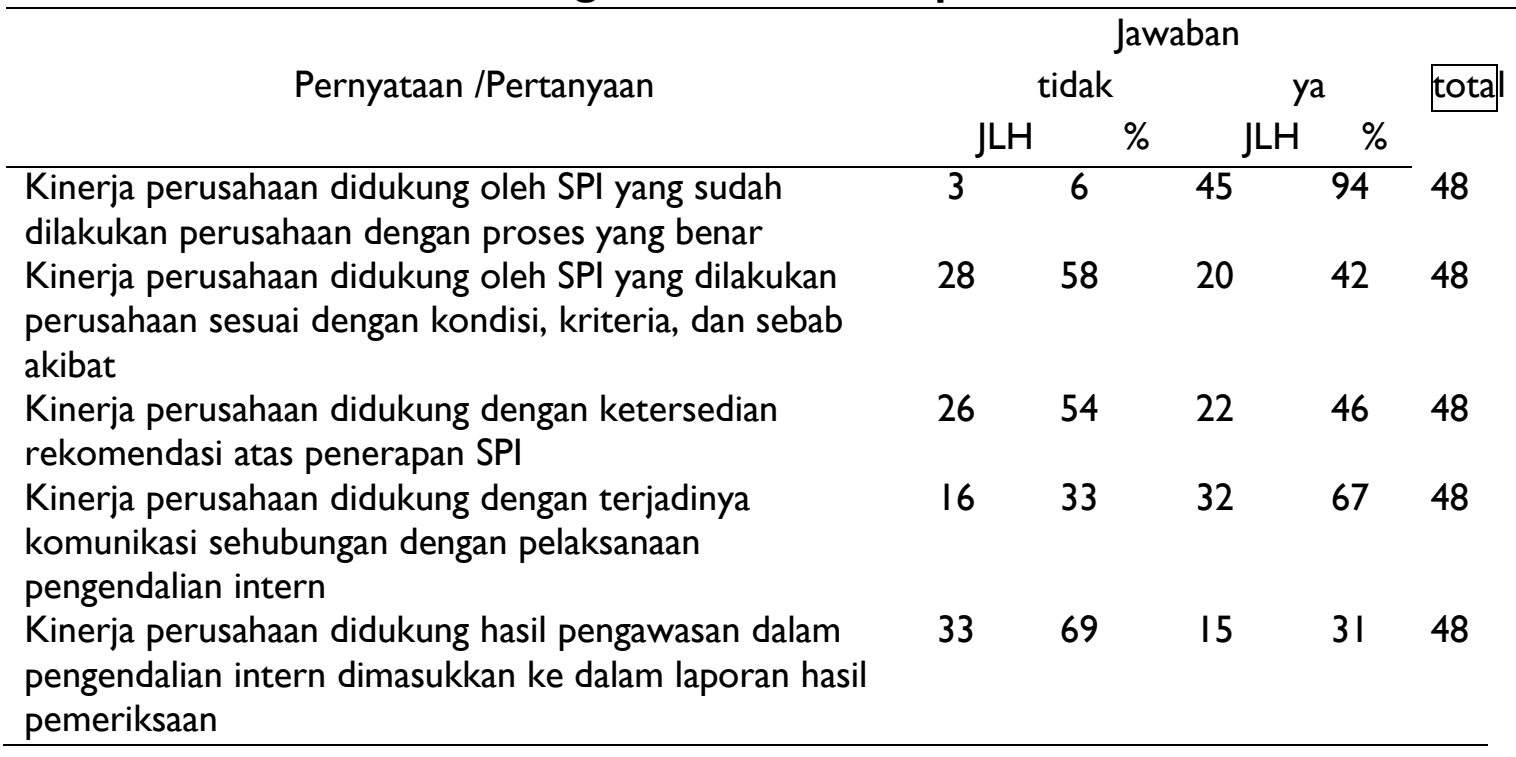

Sumber: diolah dari kuesioner penelitian, 2016

Berdasarkan hasil perhitungan atas jawaban pernyataan/ pertanyaan di atas skor terendah untuk jawaban tidak yang diberikan oleh pegawai Kantor Cabang Pembantu Bank XYZ Palembang adalah sebesar 3 I\% (item kelima) sedangkan skor tertinggi adalah 94\% (item kesatu) untuk jawaban ya. Skor tersebut masih termasuk ke dalam kategori positif/memadai. Sesuai dengan range skor responden, skor tersebut termasuk 
klasifikasi memadai. Hal ini berarti dalam pelaksanaan sistem pengendalian intern masih terdapat kendala dalam penyelesaiannya. Pihak Kantor Cabang Pembantu Bank XYZ Palembang perlu memperhatikan hasil pengawasan dalam pengendalian intern dimasukkan ke dalam laporan hasil pemeriksaan sehingga komponen tersebut jika diperbaiki atau berhasil diminimalisasi maka akan mempengaruhi skor kinerja perusahaan. Hal ini agar terjadi sinergi dalam pelaksanaan SPI yang mendukung peningkatan kinerja perusahaan.

c. Penilaian kinerja Kantor Cabang Pembantu Bank XYZ Palembang apakah didukung dengan kecukupan proses penyelesaian tindak lanjut temuan audit intern:

Tabel 7. Jawaban responden untuk mengetahui Penilaian kinerja Kantor Cabang Pembantu Bank XYZ Palembang apakah didukung dengan kecukupan proses penyelesaian tindak lanjut temuan audit intern

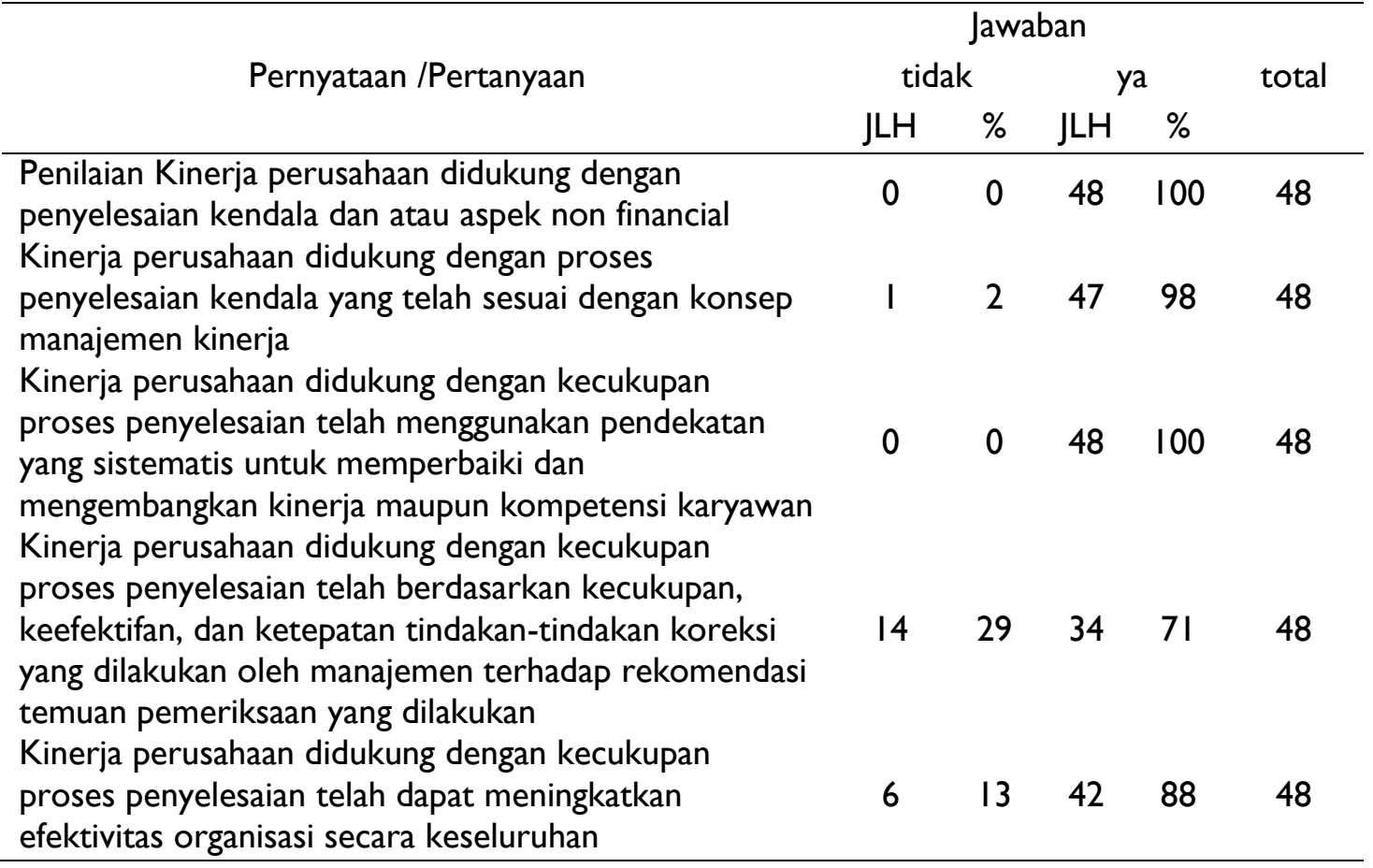

Sumber: diolah dari kuesioner penelitian, 2016

Berdasarkan hasil perhitungan atas jawaban pernyataan/ pertanyaan di atas skor terendah untuk jawaban tidak yang diberikan oleh pegawai Kantor Cabang Pembantu Bank XYZ Palembang adalah sebesar 29\% (item keempat) sedangkan skor tertinggi adalah 100\% (item kesatu dan ketiga) untuk jawaban ya. Sesuai dengan range skor responden, skor tersebut termasuk klasifikasi sangat memadai. Hal ini berarti Kantor Cabang sudah melakukan proses penyelesaian tindak lanjut temuan audit intern dalam 
rangka mendukung penilaian kinerja Kantor Cabang Pembantu Bank XYZ Palembang secara memadai. Oleh karena itu, perlu peningkatan pada kecukupan proses penyelesaian oleh perusahaan yang berdasarkan kecukupan, keefektifan, dan ketepatan tindakan-tindakan koreksi yang dilakukan oleh manajemen perusahaan terhadap rekomendasi temuan pemeriksaan.

d. Penilaian kinerja pegawai telah mencakup penyelesaian temuan audit dan atau aspek non keuangan:

Tabel 8. Jawaban Responden untuk Mengetahui Penilaian Kinerja Pegawai Telah Mencakup Penyelesaian Temuan Audit dan Atau Non Keuangan

\begin{tabular}{|c|c|c|c|c|c|}
\hline \multirow{3}{*}{ Pernyataan /Pertanyaan } & \multicolumn{4}{|c|}{ Jawaban } & \multirow{3}{*}{ total } \\
\hline & \multicolumn{2}{|c|}{ tidak } & \multicolumn{2}{|c|}{ ya } & \\
\hline & $\mathrm{JLH}$ & $\%$ & JLH & $\%$ & \\
\hline $\begin{array}{l}\text { Kinerja perusahaan didukung dengan pelaksanaan } \\
\text { unsur penilaian kinerja telah diberlakukan seluruhnya } \\
\text { kepada karyawan dan tidak hanya sebatas kepada } \\
\text { kepala cabang }\end{array}$ & 0 & 0 & 48 & 100 & 48 \\
\hline $\begin{array}{l}\text { Kinerja perusahaan didukung dengan tersedianya } \\
\text { penetapan target secara berkala dan bertahap } \\
\text { Kinerja perusahaan didukung dengan unsur penilaian }\end{array}$ & 1 & 2 & 47 & 98 & 48 \\
\hline $\begin{array}{l}\text { kinerja telah sesuai dengan konsep Management by } \\
\text { Objective }\end{array}$ & 0 & 0 & 48 & 100 & 48 \\
\hline $\begin{array}{l}\text { Kinerja perusahaan didukung dengan keterlibatan } \\
\text { seluruh karyawan untuk mencapai target yang telah } \\
\text { ditetapkan }\end{array}$ & 0 & 0 & 48 & 100 & 48 \\
\hline
\end{tabular}

Sumber: diolah dari kuesioner penelitian, 2016

Berdasarkan hasil perhitungan atas jawaban pernyataan/pertanyaan di atas skor terendah untuk jawaban tidak yang diberikan oleh pegawai Kantor Cabang Pembantu Bank XYZ Palembang adalah sebesar 2\% (item kedua) untuk jawaban "tidak” sedangkan skor tertinggi adalah 100\% (item kesatu dan kesatu, ketiga dan keempat) untuk jawaban "ya". Sesuai dengan range skor responden, skor tersebut termasuk klasifikasi memadai. $\mathrm{Hal}$ ini berarti responden sependapat bahwa penyelesaian temuan audit dan/atau aspek non finansial dimasukan sebagai unsur penilaian kinerja pegawai.

\section{Evaluasi Kinerja Kantor Cabang Pembantu Bank XYZ Palembang}

Hasil rekapitulasi evaluasi kinerja berdasarkan implementasi SPI melalui kuesioner kepada 48 (empat puluh sembilan) pegawai Kantor Cabang Pembantu Bank XYZ Palembang sebagai responden untuk masing-masing item pernyataan. Berdasarkan jawaban responden terhadap identifikasi temuan audit diperoleh hasil sebagai berikut: 
a. Apakah penilaian kinerja Proses Bisnis Kantor Cabang Pembantu Bank XYZ Palembang dipengaruhi oleh temuan audit yang sering terjadi dan berulang hal yang sama.

Berdasarkan Tabel 9, penilaian kinerja Proses Bisnis Kantor Cabang Pembantu Bank XYZ Palembang dipengaruhi oleh temuan audit yang sering terjadi dan berulang hal yang sama khususnya pada aspek manajemen kredit dominan sering sebesar 60,42\%. Sedangkan yang perlu mendapatkan perhatian khusus dari pihak manajemen karena sudah masuk ke tingkat sangat sering dengan nilai yang cukup signifikan yakni sebesar $25 \%$ tetap pada aspek manajemen kredit. Untuk mengatasi temuan audit yang sering terjadi dan berulang pada hal atau point yang sama maka pihak Kantor Cabang Pembantu Bank XYZ Palembang dan pihak Kantor Pusat dapat bekerjasama dengan pihak eksternal untuk membuat tim audit yang khusus untuk memecahkan masalah tersebut. Hal ini akan memperbaiki kinerja Kantor Cabang Pembantu Bank XYZ Palembang karena temuan audit berulang telah dapat diminimalisasi selain itu pihak Kantor Cabang Pembantu Bank XYZ Palembang juga dapat membuat kebijakan baru terkait SOP (Standar Operasional Prosedur) yang dijalankan agar lebih efektif dan efisien.

Tabel 9. Jawaban responden untuk mengetahui Kendala dalam Proses Bisnis pada Kantor Cabang Pembantu Bank XYZ Palembang

\begin{tabular}{llcccc}
\hline \multirow{2}{*}{ No } & \multicolumn{1}{c}{ Pernyataan } & jarang & Jawaban Hasil Kuesioner \\
& & $8,33 \%$ & $6,25 \%$ & $60,42 \%$ & $25 \%$ \\
\hline I & Manajemen kredit & $14,58 \%$ & $37,50 \%$ & $39,58 \%$ & $8,33 \%$ \\
2 & Manajemen dana & $14,58 \%$ & $45,83 \%$ & $35,42 \%$ & $4,17 \%$ \\
3 & Akuntansi dan pelaporan & $20,83 \%$ & $52,08 \%$ & $22,92 \%$ & $4,17 \%$ \\
4 & Logistik & $25,00 \%$ & $54,17 \%$ & $16,66 \%$ & $4,17 \%$ \\
\hline
\end{tabular}

Sumber: diolah dari kuesioner penelitian, 2016

b. Penilaian kinerja Proses Bisnis pada Kantor Cabang Pembantu Bank XYZ Palembang dipengaruhi oleh faktor yang menyebabkan proses bisnis sering menjadi temuan audit. 


\section{Tabel 10. Jawaban responden untuk mengetahui Faktor Penyebab Kendala Proses Bisnis pada Kantor Cabang Pembantu Bank XYZ Palembang}

\begin{tabular}{|c|c|c|c|c|c|}
\hline \multirow{2}{*}{ No } & \multirow{2}{*}{ Pernyataan } & \multicolumn{4}{|c|}{ Jawaban Hasil Kuesioner } \\
\hline & & jarang & kadang-kadang & sering & sangat sering \\
\hline $\mathrm{I}$ & $\begin{array}{l}\text { Prosedur yang belum } \\
\text { dijalankan }\end{array}$ & $10,42 \%$ & $39,58 \%$ & $41,67 \%$ & $8,33 \%$ \\
\hline 2 & $\begin{array}{l}\text { Kurangnya pemahaman } \\
\text { petugas }\end{array}$ & $10,42 \%$ & $52,08 \%$ & $33,33 \%$ & $4,17 \%$ \\
\hline 3 & $\begin{array}{l}\text { Keterkaitan dengan pihak } \\
\text { eksternal }\end{array}$ & $8,33 \%$ & $33,33 \%$ & $47,92 \%$ & $10,42 \%$ \\
\hline 4 & $\begin{array}{l}\text { Terkait teknologi informasi } \\
\text { perusahaan yang kurang } \\
\text { mendukung }\end{array}$ & $12,50 \%$ & $47,92 \%$ & $37,50 \%$ & $2,08 \%$ \\
\hline 5 & $\begin{array}{l}\text { Internal kontrol atasan } \\
\text { langsung yang kurang }\end{array}$ & $29,17 \%$ & $29,17 \%$ & $37,50 \%$ & $4,17 \%$ \\
\hline
\end{tabular}

Sumber: diolah dari kuesioner penelitian, 2016

Berdasarkan Tabel 10, penilaian kinerja Proses Bisnis pada Kantor Cabang Pembantu Bank XYZ Palembang dipengaruhi oleh faktor yang menyebabkan proses bisnis dominan sering menjadi temuan audit khususnya yang terkait dengan pihak eksternal sebesar 47,92\%. Sedangkan yang perlu mendapatkan perhatian khusus dari pihak manajemen karena sudah masih ke tingkat sangat sering adalah untuk semua aspek walaupun dengan persentase yang masih terbilang kecil. Hal -hal yang dapat diminimalisasi oleh pihak Kantor Cabang Pembantu Bank XYZ Palembang secara internal adalah prosedur yang dijalankan, pemahaman petugas, dan internal kontrol atasan langsung. Sedangkan untuk ketersediaan teknologi informasi yang kurang mendukung dapat diajukan ke pihak Kantor Pusat sehingga permasalahan yang menyebabkan temuan audit menjadi berlarut-larut dapat diselesaikan secara efektif dan efisien.

c. Apakah Penilaian kinerja proses bisnis pada Kantor Cabang Pembantu Bank XYZ Palembang dipengaruhi oleh lamanya penyelesaian temuan audit.

Berdasarkan tabel II, didapatkan bahwa penilaian kinerja yang berkaitan dengan proses bisnis dipengaruhi oleh lamanya penyelesaian temuan audit khususnya pada aspek manajemen kredit dominan di tingkat sering yakni sebesar 52,08\%. Permasalahan manajemen kredit umumnya dikarenakan kredit macet yang dideteksi sebagai akibat prosedur kredit yang belum dijalankan sesuai dengan standar yang ada. Sedangkan aspek manajemen dana, akuntansi dan pelaporan, logistik dan lainnya tetap perlu 
mendapat perhatian pihak manajemen Kantor Cabang Pembantu Bank XYZ Palembang yang frekuensi masing dominan kadang-kadang terjadi.

Tabel I I. Jawaban responden untuk mengetahui Proses Bisnis pada Kantor Cabang Pembantu Bank XYZ Palembang

\begin{tabular}{|c|c|c|c|c|c|}
\hline \multirow{2}{*}{ No } & \multirow{2}{*}{ Pernyataan } & \multicolumn{4}{|c|}{ Jawaban Hasil Kuesioner } \\
\hline & & jarang & kadang-kadang & sering & sangat sering \\
\hline $\mathrm{I}$ & Manajemen kredit & $6,25 \%$ & $22,92 \%$ & $52,08 \%$ & $18,75 \%$ \\
\hline 2 & Manajemen dana & $27,08 \%$ & $54,17 \%$ & $18,75 \%$ & $0,00 \%$ \\
\hline 3 & $\begin{array}{l}\text { Akuntansi dan } \\
\text { pelaporan }\end{array}$ & $37,50 \%$ & $52,08 \%$ & $8,33 \%$ & $2,08 \%$ \\
\hline 4 & Logistik & $37,50 \%$ & $52,08 \%$ & $10,42 \%$ & $0,00 \%$ \\
\hline 5 & Lainnya & $31,25 \%$ & $58,33 \%$ & $10,42 \%$ & $0,00 \%$ \\
\hline
\end{tabular}

Sumber: diolah dari kuesioner penelitian, 2016

Berdasarkan hasil rekapitulasi jawaban kuesioner untuk mengevaluasi kinerja perusahaan berdasarkan SPI yang telah diimplementasikan, menunjukkan bahwa SPI sudah dapat membantu manajemen Kantor Cabang Pembantu Bank XYZ Palembang dalam rangka meningkatkan kinerjanya. Walaupun masih terdapat beberapa kendala yang menghambat peningkatan kinerja perusahaan khususnya kendala yang lebih banyak terkait dengan pihak eksternal, kendala tidak dapat seluruhnya diselesaikan sebelum penilaian kinerja diputuskan, kendala dalam kemampuan pegawai untuk penyelesaian masalah, dukungan dana perusahaan yang dialokasikan dalam penyelesaian kendala, dan pemotivasian pegawai dalam penyelesaian masalah yang perlu ditingkatkan lagi.

Oleh karena itu, penyelesaian kendala dalam pelaksanaan pengendalian intern harus berdasarkan pada risiko dan kerugian yang terkait juga dengan tingkat kesulitan dan perlunya ketepatan waktu dalam penerapan tindakan korektif. Adanya proses bisnis yang sering menjadi temuan audit serta adanya faktor intern dan ekstern yang menyebabkan proses bisnis menjadi temuan audit harus menjadikan perusahaan memperhatikan; kemampuan pegawai, kemampuan sistem informasi dan motivasi pemberdayaan dan keserasian individu sesuai dengan perspektif pembelajaran dan pertumbuhan balance scorecard serta dipenuhinya kepuasan kerja (job satisfaction). Oleh karena itu sebaiknya pihak manajemen Kantor Cabang harus lebih sering mengikutsertakan pegawai mengikuti pendidikan dalam rangka meningkatkan kompetensinya dalam menghadapi permasalahan yang mungkin akan timbul dalam pelaksanaan operasional bisnis Kantor Cabang serta memberikan apresiasi atas 
keberhasilan karyawan dalam menyelesaikan permasalahan. Disamping itu, peran pihak Kantor Pusat juga diperlukan dalam pengawasan penerapan SPI agar kinerja Kantor Cabang menjadi lebih baik. Selain itu, menurut Dewi (2016) pengalaman kerja dan profesionalisme turut pula menunjang efektivitas sistem pengendalian internal.

\section{SIMPULAN}

Hasil penelitian ini menunjukan bahwa manajemen kinerja sudah mulai terdukung dengan penerapan SPI yang dinilai sudah memadai. Akan tetapi masih terbatasnya penerapan penilaian kinerja untuk unsur finansial menyebabkan kinerja SPI untuk penyelesaian tindak lanjut temuan audit pada Kantor Cabang dinilai belum optimal. Oleh karena itu, perlu perhatian penerapan SPI yang juga memfokuskan pada unsur non finansial yang juga sangat menunjang kinerja perusahaan baik langsung maupun tidak langsung.

Oleh karena data penelitian ini dihasilkan dari instrumen yang mendasarkan pada persepsi jawaban. Hal ini akan menimbulkan masalah jika persepsi responden berbeda dengan keadaan yang sesungguhnya. Populasi dalam penelitian ini terbatas pada Kantor Cabang, untuk itu dalam penelitian selanjutnya sebaiknya memasukan juga Divisi dan Kantor Pusat. Hal ini agar sesuai dengan konsep management by objective (MBO) yang menuntut dalam menerapkan MBO atasan bersama bawahannya untuk menetapkan target secara berkala dengan bertahap maka target penyelesaian kendala dalam sistem pengendalian intern harus juga menjadi salah satu unsur penilaian kinerja seluruh manajemen Kantor Cabang sehingga manajemen Kantor Cabang mempunyai tanggung jawab yang besar untuk memonitor pelaksanaan sistem pengendalian intern tersebut tidak hanya Kepala Cabang saja yang mempunyai kewajiban untuk menyelesaikan kendala pelaksanaan sistem pengendalian intern tersebut.

\section{PUSTAKA ACUAN}

Bank Indonesia. 20II. Peraturan Bank Indonesia Nomor I3/2/PBI/20II tanggal 12 Januari 201 I tentang Pelaksanaan Fungsi Kepatuhan Bank Umum. Jakarta: Bank Indonesia.

Bank Indonesia. 2003. Pedoman Standar Sistem Pengendalian Intern Bagi Bank Umum. Jakarta: Bank Indonesia. 
Dewi, Ratna Andita. 2016. Determinan Efektivitas Sistem Pengendalian Internal Perusahaan. Akuntabilitas. Vol. 9 (2): 255-270.

Kaplan, S. Robert and David, P. Norton. 2000. The Balanced Scorecard Translating Strategy into Action, Edisi Satu. United States of America. Harvard Business School Press.

Niswonger, Warren, Reeve, Fees, 2000. Prinsip-Prinsip Akuntansi, Edisi 19, Penerjemah: Alfonsus Sirait dan Helda Gunawan, Jilid I. Jakarta: Erlangga.

Simanjuntak, J. Payaman. 2005. Manajemen dan Evaluasi Kinerja. Lembaga Penerbit Fakultas Ekonomi Universitas Indonesia. Jakarta.

Tiasari, Hannum. 2013. Hubungan Antara Pengendalian Internal Dengan Akuntabilitas Kinerja Instansi Pemerintah Dinas Pendapatan Provinsi Jawa Timur. Kebijakan dan Manajemen Publik. Volume I, Nomor 2.

Tresnawati, Rina. 2012. Pengaruh Efektifitas Pengendalian Intern Terhadap Kinerja Instansi Pemerintah Di Dinas Pendapatan Daerah Kota Bandung. Forum Bisnis \& Keuangan I, Th. 2012. Prosiding Seminar Nasional.

Zamzami, Faiz dan Ihda Arifin Faiz. 2015. Evaluasi Implementasi Sistem Pengendalian Internal: Studi Kasus pada Sebuah Perguruan Tinggi Negeri. Jurnal Akuntansi Multiparadigma, Volume 6, Nomor 1, April 2015: 20-27. 